\title{
Phytolacca americana L. Bitkisinin Farklı Habitatlardaki Azot ve Fosfor Makro Element Değerlerinin Karşılaştırılması
}

\author{
Tuğba Özbucak (D), Arzu Sağlam \\ Ordu Üniversitesi, Fen Edebiyat Fakültesi, Moleküler Biyoloji ve Genetik Bölümü \\ Geliş Tarihi / Received Date: 21.09.2021 \\ Kabul Tarihi / Accepted Date: 01.12.2021 \\ Özet
}

Bu çalışmada Ordu ili Ünye ilçesinde farklı habitat özelliklerine sahip lokalitelerden (temiz, kirli ve sulak alan) bitkinin genç, olgun ve senesens dönemlerinde toplanan P. americana bitkisinin yapraklarında N (azot), $\mathrm{P}$ (fosfor) içerikleri incelenmiştir. Yapılan çalışma sonucunda temiz, kirli ve sulak alan olarak belirlenen farklı habitatlar arasında N (azot) ve P (fosfor) değerleri ortalamaları karşılaştıııldı̆̆ında temiz ve sulak alan habitatlarındaki değerler kirli olarak belirlenen habitattaki değerlerden yüksek çıkmıştı. N (azot) değerleri istatistiki olarak önemli bulunmuştur. Bitkinin vejetatif dönemindeki genç yapraklarının yüksek $N$ konsantrasyonuna sahip olduğu belirlenmiştir. Meyve dönemi olan olgun dönemde ise azalmaya başlayıp senesens döneminde en düşük konsantrasyonda olduğu tespit edilmiştir. İstatistiki olarak önemli bulunmayan P değerleri ise her üç lokalitede benzer sonuçlar göstermekle beraber en yüksek değerler sulak alan bölgesine aittir. Toprak analiz sonuçları değerlendirildiğinde her üç habitatın killi-tınlı, hafif alkali, az tuzlu ve kireçli özellikte olduğu görülmüştür. Bununla beraber, kirli alanın azot, fosfor ve organik madde açısından yeterli olduğu tespit edilmiştir.

Anahtar Kelimeler: azot, fosfor, büyüme mevsimi, sulak alan, kirli alan

\section{Comparison of Nitrogen and Phosphorus Macro Elements Values of Phytolacca americana L Plant in Different Habitats}

\section{Abstract}

In this study, the N (nitrogen), P (phosphorus) contents of the leaves of the P. americana plant collected in the young, mature and senescent periods of the plant from localities with different habitat characteristics (clean, polluted and wetland) in Ünye district of Ordu province were investigated. As a result of the study, when the averages of $\mathrm{N}$ (nitrogen) and $\mathrm{P}$ (phosphorus) values between different habitats determined as clean, polluted and wetland were compared, the values in clean and wetland habitats were higher than the values in the habitat determined as polluted. $\mathrm{N}$ (nitrogen) values were found to be statistically significant. It was determined that the young leaves of the plant in the vegetative period have high $\mathrm{N}$ concentration. In the mature period, which is the fruiting period, it started to decrease and was found to be at the lowest concentration in the senescence period. $P$ values, which were not found statistically significant, show similar results in all three localities, but the highest values belong to the wetland region. When the soil analysis results were evaluated, it was observed that all three habitats were clay loam, slightly alkaline, less salty and calcareous. However, it has been determined that the polluted area is sufficient in terms of nitrogen, phosphorus and organic matter.

Keywords: nitrogen, phosphorus,growth season, wetland, polluted area 


\section{Giriş}

Bitkilerdeki besin elementi konsantrasyonunun belirlenmesinde yaygın olarak kullanılan bitki kısımları yapraklardır (Bilgin vd., 2004; Güzel, 2017; Özbucak vd., 2013;). Yüksek yapılı bitkilerde önemli bir vejetatif organ olan yaprak, mekâna ve zaman bağlı olarak önemli varyasyonlar göstermektedir. Yaprağın bu özellikleri büyük bir dinamizm sergileyen ekosistemlerde bitki-bitki, bitki-çevre ilişkileri ve küresel değişimler hakkında değerlendirmeler yapılmasına imkân sağlamaktadır (Yalçın, 2018). Özellikle yaprak besin elementleri ekosistemlerde dolaşımdaki karbondioksit miktarının artması, küresel ısınma, kuraklık, aşııı azot birikimi ve istilacı türlerin artışı gibi değişimlerle korelasyon sergilemektedir (Penuelas vd., 2013). Azot (N) ve Fosfor (P) ekosistem fonksiyonları ve dinamiklerinde önemli rol oynayan iki önemli yaprak besin elementidir. Ayrıca hem karasal hem de sucul ekosistemlerde bitki büyüme ve gelişimini sınırlayan iki önemli bileşendir (Bilgin ve Güzel, 2017; Kılıç vd., 2012; Kutbay, 2001; Milosevic vd., 2009; Özbucak vd., 2011). Bitkilerin fotosentetik performansını etkileyen azot ve fosforun bitkinin beslenme durumunu ortaya koyduğu bilinmektedir (Demirayak vd., 2011; Orgeas vd., 2002). Aynı zamanda azot ve fosfor hücreden ekosisteme kadar bütün biyolojik sistemlerde önemli fonksiyonlara sahiptir. Farklı ekosistemler arasında birlikte ve karşııklı etkileşimleri yaygındır (Bilgin ve Güzel, 2017; Gong vd., 2020).

Aminoasit, protein, nükleik asit gibi önemli organik bileşiklerin yapısında bulunan azot, bitkide yeni hücrelerin meydana gelebilmesi için zorunlu bir makro elementtir. Eksikliğinde bitkideki büyüme oranı azalmakta özellikle bitkinin vejetatif gelişmesi olumsuz olarak etkilenmektedir. Aynı şekilde kök gelişmesi ile kök dallanması da zayıflamaktadır (Erbaş ve Şenateş, 2020; Gudade vd., 2009). Azotun fazlalığı ise bitkinin vejetatif gelişme periyodunu uzatarak çiçeklenmeyi geciktirmekte, meyvelerin geç olgunlaşmasına ve mantar hastalıklarına karşı dayanıkıılığın azalmasına neden olmaktadır (Aktaş ve Ateş, 1998; Boşgelmez vd., 2001; Fageria vd., 2011).

Tüm organizmalar için gerekli elementlerden birisi olan fosfor bitkilerde protein, enzim, koenzim, nükleik asit ve fosfolipid gibi moleküllerin önemli bileşenidir. Fosfor bitkilerde ATP ile nükleik asitlerin meydana gelmesi için zorunlu bir element olmasından dolayı büyük miktarda ihtiyaç duyulan bir makro elementtir. Bununla beraber, bitkilerin olgunlaşmasını erken büyüme, çiçeklenme, tohum bağlama ve kök oluşumunu teşvik ederek, tohum/meyve üretimini artırmaktadır (Kulaç ve Bildirici, 2020). Fosfor eksikliğinde de genel olarak azot eksikliğinde ortaya çıkan belirtiler görülmekte olup bitkideki gelişim süreçleri etkilenmektedir. Ayrıca bitkilerdeki yaprak yüzey alanı ile gelişimi önemli miktarda azalma göstermektedir (Bayram vd., 2004). Fosforun fazla olmasının bitkiler üzerinde meydana getirdiği etki daha çok dolaylı bir şekilde görülür. Bu durum sık karşılaşılan bir durum olmamakla birlikte fazlalığında çinko ve demir gibi mikro besin elementlerinin eksikliği oluşmaktadır (Aktaş ve Ateş, 1998).

Çalışmamızın materyalini oluşturan Phytolacca americana L. bitkisi özellikle doğu Karadeniz bölgesinde yaygın olarak bulunmaktadır (Tubives, 2014). Yörede Şekerciboyası, Acımur, Dünya güzeli isimleri ile bilinir (Baytop, 1994). İstilacı bir yabancı ot olan bitki tarla bitkileri, çayır ve mera alanları gibi farklı yerlerde sorun oluşturabilmektedir. P. americana L. taksonunun tedavi, gıda ve hayvan yemi olarak kullanıldığı ancak zehirli olduğu için kullanımına dikkat edilmesi gerektiği bildirilmiştir (Baytop 1994; Nabavi vd., 2009a). Bitkinin tıbbi olarak müshil, ağrı giderici, antiinflamatuar, anti romatizma ve antiartritik aktivitelere sahip olduğu, ayrıca çeşitli cilt hastalıklarının tedavisi için de uygun olduğu bildirilmiştir (Goldestein vd.,1973; Mumcu ve Korkmaz, 2018). Bitkinin, Mn ve Cd ile kirlenmiş toprakların ıslahı için büyük bir potansiyele sahip, iyi bir $\mathrm{Mn}$ ve $\mathrm{Cd}$ hiperakümülatörü olduğu tespit edilmiştir (Min ve ark. 2007). Bununla beraber, hücre duvarında ligninin immobilizasyonu, şelasyon, vakuolar kompartmanizasyon ve ayrıca tiyol bileşikleri içeriğinin artmasının hiperakümülatör bitki $P$. americana'da Cd detoksifikasyonunun önemli mekanizmaları olabileceğini göstermiş̧tir (Zhao vd., 2021).

Bu çalışmanın amacı Ordu ili Ünye ilçesinde farklı habitat özelliklerine sahip temiz, kirli ve sulak alan olarak belirlenen lokalitelerden toplanan $P$. americana bitkisinin genç, olgun ve senesens dönemlerindeki yapraklarında N (azot), P (fosfor) içeriklerini incelemektir. "Farklı ekolojik ortamların 
bitkinin N,P makro elementlerinin profili üzerinde değişikliğe neden olabileceği" hipotezi ile yapılan bu çalışmanın bu ve benzer konularda yapılacak çalışmalara ışık tutacağı kanaatindeyiz.

\section{Materyal ve Yöntem}

\subsection{Materyal}

Çalışmamızın materyalini oluşturan Phytolacca americana bitkisi Phytolaccaceae Familyasına ait Phytolacca cinsine ait bir taksondur. Takson, 0-500 m rakımları arasında yayılış gösteren, Haziran-Eylül ayları arasında çiçeklenen, çok yıllık, otsu formunda yamaçlar, tarlalar ve çalıık habitatları yaşam alanı olarak tercih eden bir bitkidir (Davis, 1984). Takson Tubives kayıtlarına göre ülkemizde kuzey ve güney Anadolu'da yayılış göstermektedir (Şekil 1).

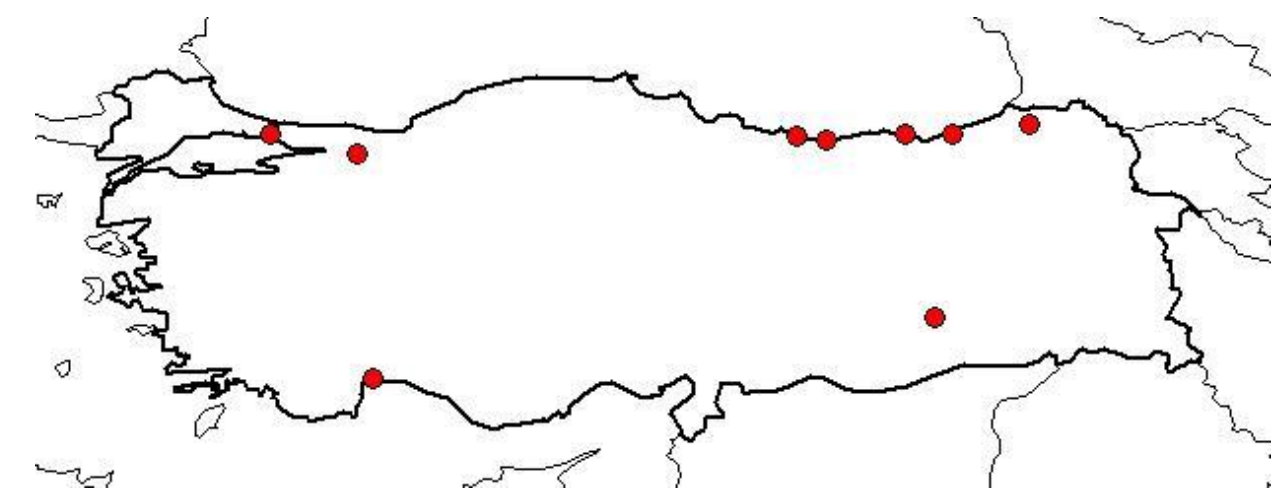

Şekil 1. Phytolacca americana L. Taksonunun Türkiye Üzerindeki Dağlımı (İstanbul, Antalya, Artvin, Diyarbakır, Giresun, Ordu, Rize, Sakarya, Trabzon)

Şekerci boyası olarak bilinen bitki genelde 1-3 metre boyunda ve dalları 1-2 metre çapında yayılabilen otsu bir bitkidir. Yaprakları genellikle büyük, saplı veya sapsız, çok çiçekli olup, çiçekler hermafrodit veya işlevsel olarak unisexual, periant segmentleri küçük, stamenleri 10 veya nadiren daha fazladır. Bitki çabuk büyüyen ve yayılan kazık bir köke sahiptir. Yaprakları kendine has hoş olmayan bir kokuya sahiptir. Başlangıçta kırmızımsı renkte olan üzümsü ve sulu olan meyve ileriki dönemde siyaha dönmektedir. (Anonim, 2014b; Sellers ve Ferrell, 2013) (Şekil 2). Parlak siyah renkte, yuvarlağımsı olan tohumları $10 \mathrm{~mm}$ çapındadır. Tohumları yaklaşık 40 yıl çimlenmeden dormant halde canlılığını koruyabilmektedir. Hem güneş hem de gölgelik alanlarda rahatlıkla büyüyebilen bitki sahip olduğu güçlü ve derin kök sistemi sayesinde yangınlardan dahi etkilenmemektedir. Yangından sonra köklerinden yeniden büyüyerek hayatını devam ettirir. Genellikle sulak alan ve orman kenarlarında, ruderal alanlarda, sahile yakın yerlerde ve yerleşim yerlerinin civarında bitkinin yoğun olarak bulunduğu tespit edilmiştir. Terk edilmiş tarla ve bahçelerde de bitkiye rastlanmasına rağmen, tarım yapılan alanlarda bitkiye yoğun olarak rastlanmamıştır. Tarım alanlarının etrafında ve tarım dışı alanlarda yoğun olarak bulunmaktadır.

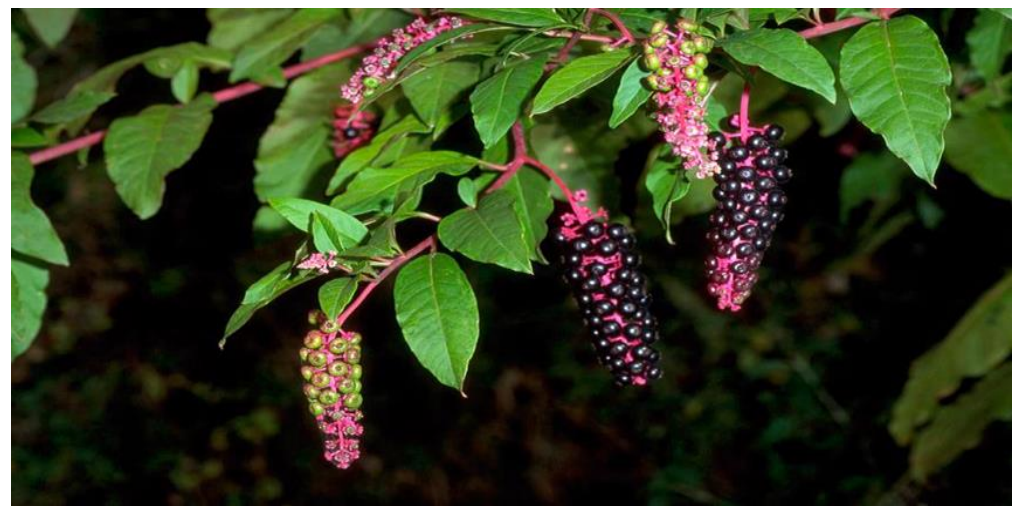

Şekil 2. Phytolacca americana L. Taksonunun Genel Görünüşü 


\subsection{Metot}

Bu çalışmada Ordu ili Ünye illçesinde farklı habitat özelliklerine sahip üç farklı lokaliteden toplanan $P$. americana örnekleri ile çalışılmıştır. Çalışmada habitat özelliklerinin belirlenmesinde bitkinin seçilen bütün alanlarda yaygın olarak bulunması, bir/birden çok çevresel kirleticiye maruz olması (kirli alan), kirleticilerden uzak olması (temiz alan) ile su ekosistemine yakın olması (sulak alan) kriterleri esas alınmıştır. Bu kriterlere göre belirlenen lokaliteler ve özellikleri aşağıda verilmiştir;

Çalışma materyalini topladığımız kirli alan olarak belirlediğimiz bu lokalite, deniz seviyesi rakımında $41^{\circ} 11^{\prime} 34.28^{\prime \prime}$ kuzey paralelleri ile $37^{\circ} 32^{\prime} 72.76^{\prime \prime}$ doğu meridyenleri arasında yer alan Ünye merkez Çimento fabrikası yakınıdır. Bu lokalitede bitki genellikle yol kenarını ve ot ile çalıların bol bulunduğu alanları tercih etmektedir. Çimento fabrikasına yaklaşık 300-400 m mesafede bulunmaktadır. Bitki hem çimentodan salınmakta olan gazlara (toz, sülfür dioksit, azot oksitler, ağır metaller gibi) maruz kalmakta hem de yoldan geçmekte olan motorlu taşıtların egzos gazlarına maruz kalmaktadır.

Temiz alan olarak belirlediğimiz lokalite 350 m yükseklikte, $40^{\circ} 98^{\prime} 42.43^{\prime \prime}$ kuzey paralelleri ile $37^{\circ} 10^{\prime} 766.81^{\prime \prime}$ doğu meridyenleri arasında yer alan Çaybaşı ilçesinde bulunmaktadır. Bu lokalitede bitki genellikle çalı ile fındık, meşe, gürgen gibi ağaç formlarının bol bulunduğu alanları tercih etmektedir. Bitki gübreleme yapılmayan fındık bahçesinin etrafından toplanmıştır. Fındık bahçesi orman alanıyla bitişik olarak bulunduğu için bu lokalitedeki bitki bol oksijene ve gölgeye maruz kalmaktadır.

Çaybaşı ilçesinde sulak alan olarak belirlediğimiz lokalite 200 m yükseklikte, 4099'29.86" kuzey paralelleri ile 3709'15.19" doğu meridyenleri arasındadır. Bu lokalitede bitki genellikle çalılıkların alt kısımlarını ve kenarını tercih etmektedir. Bitki örneklerinin alındığı alan bir nehir kenarı olup etrafı çalııklar ve mısır tarlasıyla çevrilidir.

Araştırma alanlarına ait iklimsel veriler Ordu Meteoroloji İstasyon Müdürlüğü'nden alınmıştır. Ordu îli SKYi (Sonbahar, Kış, Yaz, Illkbahar) Doğu Karadeniz Oseyanik yağış rejiminin 1.tipinin etkisinde bulunmaktadır. Bu iklim kurak mevsimin olmaması ile karakterize edilir (Akman, 2011). Ordu ili Meteoroloji İstasyon Müdürlüğü'ne ait Ünye ilçesine ait iklimsel veriler ve iklim diyagramı sırasıyla Şekil 3'te gösterilmiştir. İklim verilerine göre Ünye' de 1961-2020 yılları arasındaki yıllık ortalama sıcaklık 14.3 o C'dir. Yıllık ortalama yağış miktarı ise $97,64 \mathrm{~mm}$ dir.

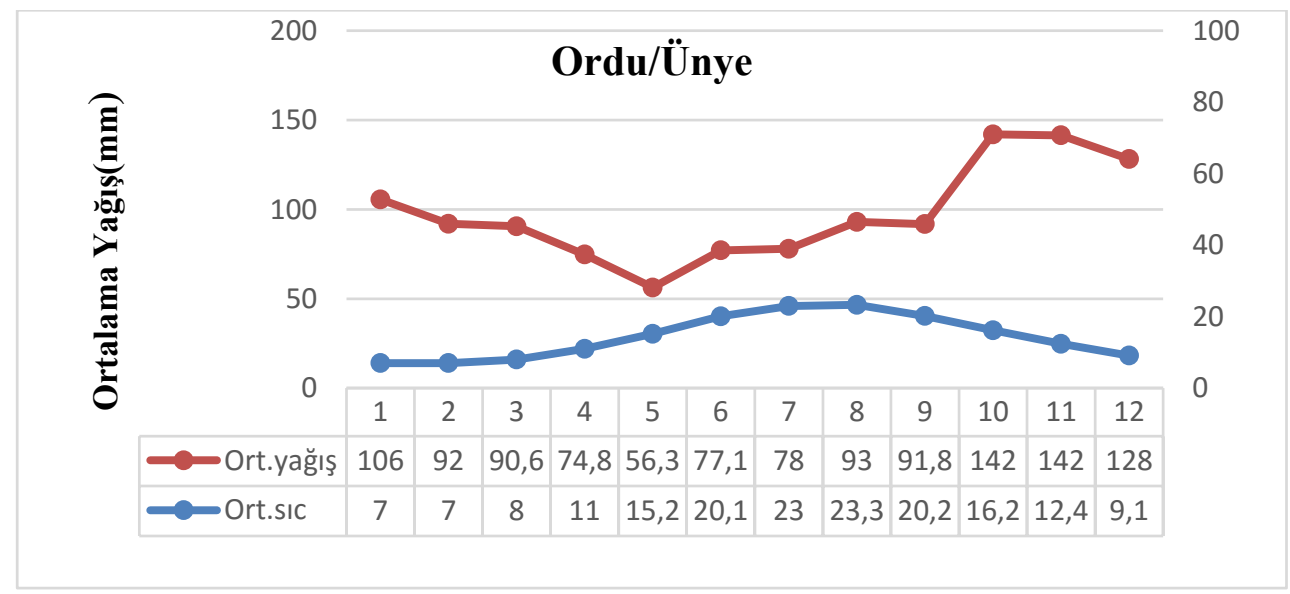

Şekil 3. Ordu ili Ünye İlçesi'nin 1961-2019 Yıllarına Ait İklim Diyagramı

Ordu ili Çaybaşı ilçesine ait iklimsel veriler ve iklim diyagramı ise Şekil 4'te gösterilmiştir. Çaybaşı illçesi'nin bölgedeki meteoroloji istasyonu yakın tarihte kurulduğu için 2015-2020 yıllarına ait verileri bulunmaktadır. Çaybaşı İlçesinde 2015-2020 yılları arasındaki yıllık ortalama sıcaklık 11.22 @ C'dir. Yıllık ortalama yağış miktarı ise $111,63 \mathrm{~mm}$ dir. 


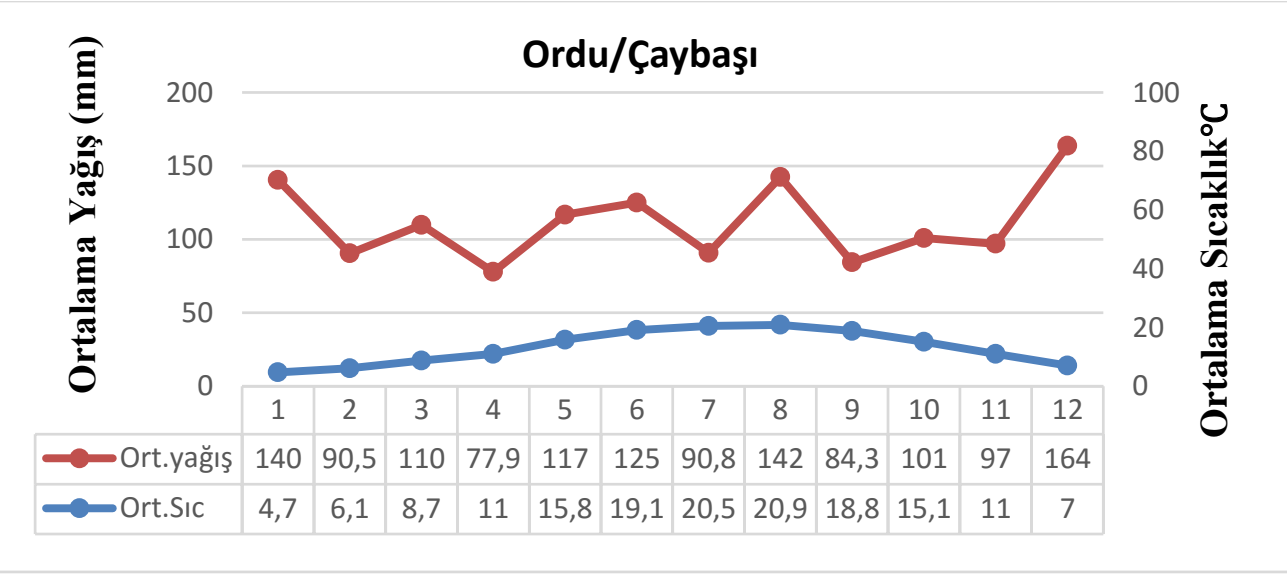

Şekil 4. Ordu ili Çaybaşı İlçesi'nin 2015-2020 yıllarına ait iklim diyagramı

Araştırma yapılan lokalitelerdeki örnek parsellerin seçiminde yön, yükseklik, vejetasyonun örtü durumu ile parsellerde en az 15 tane bireyin bulunmasına dikkat edilmiştir (Boerner ve Koslowsky, 1989). Ayrıca bitkiler genç, olgun ve senesens olmak üzere üç farklı gelişme döneminde toplanmıştır. Toplanan bitki örneklerinin tayini Davis'in "Flora of Turkey and East Aegan Island" adlı eserinden faydalanılarak yapıımıştır (Davis, 1984). Çalışmada araştırma materyalini oluşturan bitki örnekleri 65 ${ }^{\circ} \mathrm{C}^{\prime}$ de 72 saat kurutulup bitki öğütme değirmeninde öğütülerek azot ve fosfor analizine hazır hale getirilmiştir. Azot analizi numuneler selenyum katalizörü ile konsantre $\mathrm{H}_{2} \mathrm{SO}_{4}$ ile muamele edildikten sonra bir Kjeltec Auto 1030 Analyzer (Tecator, İsveç) cihazında mikro Kjeldahl yöntemiyle belirlenmiştir. $\mathrm{P}$ analizi için örnekler nitrik ve perklorik asit karışımı ile yaş yakma yapıldıktan sonra Amonyum-molibdat- Stannus klorid metodu ile spektrofotometrik olarak belirlenmiştir. Fosfor analiz yönteminin prensibi, yaş yakma yöntemi ile yakılmış bitki örneğinin Barton çözeltisi ile renklendirildikten sonra oluşan rengin indensitesinin standart seriye karşılık spektrofotometrede belirlenmesi esasına dayanır (Allen vd., 1986).

$\% \mathrm{~N}$ ve $\mathrm{P}$ sonuçları tek-yönlü varyans analizi (One-way ANOVA) ile değerlendirilmiştir. Varyans analizi sonrasında gerekli olması durumunda farklı ortalamalar Tukey çoklu karşılaştırma testi ile belirlenmiştir. Varyans analizleri öncesinde varsayımların kontrolü Levene testi ve KolmogorovSmirnov testi ile yapılmıştır. Hesaplamalarda ve yorumlamalarda \%5 önemlilik düzeyi dikkate alınmıştır. Tüm hesaplamalar Minitab 19 (Minitab LLC., USA) istatistik programı ile yapılmıştır.

Çalışılan her üç lokaliteden araziyi temsil edebilecek şekilde toprak örnekleri alınmıştır. Toprak örneği almak amacıyla öncelikle üstteki organik tabaka kaldırılarak açılan çukurlardan A horizonuna ait olmak üzere $30 \mathrm{~cm}$ derinliklerden toprak örnekleri alınmıştır. Toprak örnekleri polietilen poşetler ile laboratuvara getirilip hava kurusu durumuna gelinceye kadar kurutulmuştur. Kurutulan toprak örnekleri analizlerin yapılması amacı ile 2 ve $0.5 \mathrm{~mm}$ 'lik elekten geçirilerek analiz için hazır hale getirilmiştir. Organik madde miktarı (\%) Walkkey - Black metodu ile, $\mathrm{N}(\%)$ miktarı mikro-Keldal metodu ile, P (\%) miktarı Amonyum-molibdat- Stannus klorid metodu ile $\mathrm{K}(\%)$ miktarı, $\mathrm{Ca}(\%)$ ve $\mathrm{Mg}(\%)$ miktarları ise atomik absorbsiyon spektrofotometre ile belirlenmiştir. Topraktaki \% nem miktarının belirlenmesi toprağın yaş ve kuru ağırlık farkının tespiti ile ortaya konulmuştur. Bouyoucus hidrometre metodu ile toprak ie toprak tekstür analizi, pH metre ile de pH'sı ölçülmüştür (Kaçar, 1984).

\section{Bulgular ve Tartışma}

$\% \mathrm{~N}$ ve \%P için yapılan tek-yönlü varyans analizi tablosu Tablo 1 ve 2'de verilmiştir. Yapılan varyans analizi sonucunda \%P için gruplar arasında istatistiksel olarak önemli farklılık bulunmazken ( $>0.05)$, $\% \mathrm{~N}$ için gruplar arasındaki farklııık istatistiksel olarak önemli bulunmuştur $(p<0.001)$. Gruplar arasındaki farklıık Tukey çoklu karşılaştırma testi ile belirlenmiş ve sonuçları ortalamaların yanında harfli gösterim şeklinde ifade edilmiştir (Tablo 3). 
Tablo 1. \%N için Varyans Analizi Tablosu

\begin{tabular}{lccccc}
\hline $\begin{array}{l}\text { Varyasyon } \\
\text { Kaynağı }\end{array}$ & $\begin{array}{c}\text { Serbestlik } \\
\text { Derecesi }\end{array}$ & $\begin{array}{c}\text { Kareler } \\
\text { Toplamı }\end{array}$ & $\begin{array}{c}\text { Kareler } \\
\text { Ortalaması }\end{array}$ & F & p \\
\hline Grup & 9 & 141,032 & 15,6702 & 62,99 & 0,000 \\
Hata & 19 & 4,727 & 0,2488 & & \\
Genel & 28 & 145,759 & & & \\
\hline
\end{tabular}

Tablo 2. \%P için Caryans Analizi Tablosu

\begin{tabular}{lccccc}
\hline $\begin{array}{l}\text { Varyasyon } \\
\text { Kaynağı }\end{array}$ & $\begin{array}{c}\text { Serbestlik } \\
\text { Derecesi }\end{array}$ & $\begin{array}{c}\text { Kareler } \\
\text { Toplamı }\end{array}$ & $\begin{array}{c}\text { Kareler } \\
\text { Ortalaması }\end{array}$ & F & P \\
\hline Grup & 8 & 0,02014 & 0,002517 & 0,68 & 0,707 \\
Hata & 18 & 0,06706 & 0,003726 & & \\
Genel & 26 & 0,08720 & & & \\
\hline
\end{tabular}

Tablo 3. \% N ve P Sonuçları için Tanıtıcı İstatistik Değerleri $(n=3)$

\begin{tabular}{|c|c|c|c|c|}
\hline \multirow[b]{2}{*}{ Habitat } & \multicolumn{2}{|c|}{$\% \mathrm{~N}$} & \multicolumn{2}{|c|}{$\% \mathrm{P}$} \\
\hline & Ortalama & $\begin{array}{c}\text { Standart } \\
\text { Sapma }\end{array}$ & Ortalama & $\begin{array}{c}\text { Standart } \\
\text { Sapma }\end{array}$ \\
\hline $\begin{array}{l}\text { Temiz Alan } \\
\text { Genç }\end{array}$ & $8.100^{A}$ & 0.608 & 0.190 & 0.064 \\
\hline $\begin{array}{l}\text { Temiz Alan } \\
\text { Olgun }\end{array}$ & $7.867^{\mathrm{A}}$ & 0.635 & 0.141 & 0.025 \\
\hline $\begin{array}{l}\text { Temiz Alan } \\
\text { Senesens }\end{array}$ & $5.767^{B C}$ & 0.473 & 0.226 & 0.064 \\
\hline $\begin{array}{l}\text { Kirli Alan } \\
\text { Genç }\end{array}$ & $4.833^{C D}$ & 0.153 & 0.203 & 0.012 \\
\hline $\begin{array}{l}\text { Kirli Alan } \\
\text { Olgun }\end{array}$ & $4.033^{\mathrm{DE}}$ & 0.987 & 0.211 & 0.055 \\
\hline $\begin{array}{l}\text { Kirli Alan } \\
\text { Senesens }\end{array}$ & $3.000^{\mathrm{E}}$ & 0.361 & 0.170 & 0.043 \\
\hline $\begin{array}{l}\text { Sulak Alan } \\
\text { Genç }\end{array}$ & $7.167^{A B}$ & 0.416 & 0.237 & 0.025 \\
\hline $\begin{array}{l}\text { Sulak Alan } \\
\text { Olgun }\end{array}$ & $7.433^{\mathrm{A}}$ & 0.115 & 0.193 & 0.134 \\
\hline $\begin{array}{l}\text { Sulak Alan } \\
\text { Senesens }\end{array}$ & $6.767^{\mathrm{AB}}$ & 0.231 & 0.204 & 0.033 \\
\hline TANIK & $0.300^{\mathrm{F}}$ & 0.000 & 0.000 & 0.000 \\
\hline p-değeri & \multicolumn{2}{|c|}{$0.000 * * *$} & \multicolumn{2}{|c|}{0.707} \\
\hline
\end{tabular}

**: $p<0,01$ Ortak harfi olmayan kimyasal ortalamaları arasında fark vardır $(p<0,05)$

Tablo 3'e bakıldığında temiz ve sulak alanların N değeri ortalamalarının kirli alan ortalamalarından daha yüksek olduğu görülmektedir. İstatistiki açıdan önemli bulunmayan P değerleri ise her üç lokalitede benzer sonuçlar göstermekle beraber, en yüksek değerler sulak alan bölgesine aittir. Bitkilerin başlıca makroelementlerinden olan $\mathrm{N}$ ve $\mathrm{P}$, hem sucul hem de karasal ekosistemlerde büyümeyi sınırlayan önemli makro elementlerdir (Li vd., 2013). Azot ve fosfor varlığının/kullanılabilirliğinin birlikte ve karşılıklı etkileri farklı ekosistemler arasında yaygındır (Bilgin ve Güzel, 2017). Bitkinin hayat döngüsü sırasında oluşan farklı fizyolojik olaylar bitkinin besin elementi içeriğinde mevsimsel değişikliklerin meydana gelmesine neden olmaktadır (Güzel, 2017). Bitkiler bazen aynı toprak ve çevre şartlarında büyüseler bile bulundukları toprağın besin elementlerinden farklı oranlarda yararlanabilirler (Wrona, 2006). Yapılan çalışmada temiz, kirli ve sulak alan olarak belirlenen farklı habitatlar arasında azot değerleri ortalamaları karşılaştırıldığında temiz ve sulak alan habitatlarındaki azot değerleri kirli olarak belirlenen habitattaki değerlerden yüksek çıkmıştır. Sonuçlar Jones vd., (1991) tarafından belirtilen sınır değerlere göre de yüksek olarak değerlendirilmektedir. Elde edilen veriler istatistiki olarak önemli bulunmuştur (Tablo 3). Besin elementi açısından fakir habitatlardaki bitkilerde düşük gelişim nedeniyle 
düşük besin elementi ihtiyacı olması durumu göze çarpmaktadır Clarkson (1967), Grime (1977), Chapin (1980), De Mars ve Boerner (1997) tarafından çevresel stres şartlarının azot emilimini azaltabileceği bildirilmiştir. Kirli alan olarak belirlenen habitatın bir fabrika yakınında olması bölgenin kirlilik yükünü arttırmakta olup bitkiyi strese sokmuş olabilir. Bununla beraber, ağır metaller, bitkinin stoma iletkenliğini etkileyerek fotosentez üzerinde olumsuz bir etki oluşturabilmektedir. Artan ağır metal toksisitesi ile toprakta su yeterince bulunsa dahi bitki su alamamaktadır. Yapraklardaki suyun azalması ile stomalar kapanmakta, artan yaprak sıcaklığıyla membran sistemleri zarar görmekte ve hücre ölümleri gerçekleşmektedir. Ayrıca ağır metaller N ve karbonhidrat metabolizmalarını değiştirerek birçok fizyolojik değişikliğe neden olmaktadırlar (Dağhan vd., 2013; Sheoran vd., 1990). Bu da yapraklarda bulunan $\mathrm{N}$ elementinin fotosentetik kapasite ile yakın ilişkisi olduğunu göstermektedir.

Yaprakların besin elementi içeriği yaprağın alındığı ortama, sürgünün ait olduğu döneme, mevsime, yükseltiye, bitkinin meyveli ya da meyvesiz oluşuna, yaprağın büyüklüğü ile sağlıklı olup olmaması gibi faktörlere göre değişebilmektedir (Bhargava ve Dhandar, 1987; Roche vd., 2004). Bununla beraber farklı ekolojik şartlar, bitkinin yaşı, gelişme durumu, gibi faktörler bitkilerin topraktan alacağı besin elementi miktarlarını farklı oranlarda etkileyebilir (Erdal vd., 2008). Temiz ve sulak alan olarak belirlediğimiz alanların etrafı ormanlarla (Felek Dağı Ormanı) çevrilidir. Bu durum bu habitatlardaki örneklerde azot içeriğinin yüksek çıkmasının sebebi olabilir. Bu bölgelerden yağışlar ile gelebilecek besin elementleri bitkinin farklı gelişim dönemlerinde azotun yüksek çıkmasına neden olmuş olabilir. Artan yağış toprak besin elementi miktarını ve bitkide alınımını arttırabilir (Chen vd., 2021). Ayrıca yağış ve sıcaklık bitkide besin elementlerinin geri emilim stratejilerinin belirlenmesine katkı sağlayan itici ana güçler olabilir. Bölgesel ve yerel ölçekte, yağış toprak nemini ve verimliliğini etkileyen kilit bir faktördür (Xu vd., 2021). Çaybaşı ilçe sınırları içerisinde bulunan bu bölgeye ait iklim verilerine bakıldığında yağışın fazla, sıcaklığın daha düşük olduğu görülmektedir. Karasal ekosistemler içerisinde ormanların mekansal dağılımı oldukça geniş bir alan kaplamaktadır. Farklı habitatları bünyesinde bulunduran ormanlar önemli biyolojik çeşitlilik kaynaklarıdır (Hunter ve Jr, 1999; Klenner vd., 2009; Mori vd., 2017). Karasal ve denizel ekosistemde yaklaşık olarak $4 \times 10^{15}$, atmosferde ise $2 \times 10^{15}$ ton azot bulunmaktadır. Bunun yanında her yıl toprağa $\% 70$ 'i biyolojik azot fiksasyonu ile $\% 15^{\prime} i$ yapay gübrelerle, $\% 15^{\prime} i$ doğal gübrelerle, \%10'u çevresel kirleticiler yoluyla 200-300 milyon-ton azot kazandırılmaktadır. Dünyada biyolojik yolla toprağa sağlanan toplam azotun büyük bir kısmı orman, çayır gibi alanlardan, diğer kısmı ise okyanus ve denizlerden sağlanmaktadır (Anonim 2). Bitkinin farklı gelişme dönemlerine ait azot içeriklerinde de benzer sonuçlar görülmüştür. Bununla beraber, bütün habitatlarda bitkinin genç olduğu dönemlerdeki azot değerleri senesens değerlerinden yüksek bulunmuştur. Bitkilerin genç yaprakları yüksek fotosentez kapasitesine sahip olduğu için daha fazla azot içeriğine sahip olma gibi bir stratejiye sahiptirler (Pastor-Pastor vd., 2015). Bizim çalışmamızda da bitkinin vejetatif dönemindeki genç yapraklarının yüksek $N$ konsantrasyonuna sahip olduğu, meyve dönemi olan olgun dönemde azalmaya başlayıp senesens döneminde en düşük konsantrasyonda olduğu tespit edilmiştir. Kılıç vd. (2010) tarafından yapılan çalışmada da yaprak döken türlerde besin elementi içeriğinin genç yaprak fazında oldukça yüksek, senesens döneminde ise düştüğü belirtilmiştir. İstatistiki olarak önemli farklılıklar görülmeyen fosfor değerlerine bakıldığında en yüksek değer sulak alan habitatında daha sonra kirli ve temiz alan habitatında belirlenmiştir. Bu durum genç ve olgun döneme ait veriler ile de benzerlik göstermektedir. Senesens döneminde ise en yüksek fosfor değerleri temiz alan ve sulak alanda, en düşük değerler ise kirli alanda tespit edilmiştir. Fosfor sonuçları Jones vd. (1991) tarafından belirtilen sınır değerlere göre yüksek olarak değerlendirilmektedir. Fosfor sulak alanların verimliliğini etkileyen besin elementlerinin en önemlisi olup su ortamlarında meydana gelen ötrofikasyonun en temel nedenidir. Doğal sularda fosforun miktarı bölgenin topografik özelliklerine, suya karışan organik madde miktarı ile evsel ve endüstri atık miktarına göre değişmektedir (Taş vd., 2010). Çalışmamızda sulak alan olarak belirlenen habitat riparian alan özelliğindedir. Riparian alan ekolojide akarsu, göl ve sulak alanların kenarında doğal vejetasyona sahip taşkın yatakları olarak tanımlanmaktadır. Geçiş zonu özelliğindeki bu ekosistemler bitişiklerindeki sucul ekosistem ile etkileşim halindedirler (Özbucak ve Taş, 2016). Bu alanlar sahip oldukları yoğun bitki örtüsü ile akarsu kenarlarında bir bariyer gibi fonksiyon göstererek suları süzer, akarsu kenarlarını tutar ve alanın kirliliğini hafifletirler (Yılmaz ve 
Çiçek, 2002). Su akış havzasından gelen besin elementlerini sudan uzaklaştırarak biyolojik arıtım yapmaktadırlar. Bu da bu habitatların ötrofikasyonunu arttırarak istilacı türlerin kolonizasyonuna uygun bir hale getirmektedir (Taş vd.,2015). Bu durum çalışma materyalimiz olan istilacı P. americana taksonunun belki de bu habitatlarda yayılış göstermesinde etkisi olmuş olabilir. Kirli alan olarak seçtiğimiz fabrika yakınındaki habitatta fosfor değerlerinin genç ve olgun dönemde yüksek çıkmasının nedeni alanın özellikle fındık tarım alanlarına yakın olması olabilir. Bölge aynı zamanda Ordu-Samsun karayoluna yakın bir mevkidedir. Ayrıca fabrikadan ortama bırakan ve bölgeyi kirleten ağır metal gibi çevresel kirleticilerin bitkilerde temel besin maddelerinin eksikliğinden dolayı kök, gövde, yaprak gibi morfolojik özelliklerinde küçülme ve azalma meydana getirdiği bildirilmiştir (Jayakumar vd., 2007; Mengoni vd., 2000). Aynı zamanda ağır metallerin etkisiyle kloroplast yapısında meydana gelen değişiklik bitkide klorofil miktarının azalmasına neden olmaktadır (Akçin vd., 2017; Tunç ve Şahin, 2015; Yerli vd., 2020). Dağhan vd. (2013) tarafından yapılan çalışmada $\mathrm{Zn}, \mathrm{Cu}, \mathrm{Cd}$, Ni gibi ağır metallerinin artan dozlarının bitkilerin N, P ve K alımını azalttığı belirlenmiştir. Çalışmamızda kirli alandan almış olduğumuz yaprak örneklerimizin diğer alanlardan aldığımız örneklere göre kahverengiye dönük bir renge sahip olmaları bitkinin ağır metale maruz kaldığının bir göstergesi olabilir.

Bitki yapraklarındaki besin elementi miktarlarının belirlenmesi aynı zamanda bitkinin besin elementi döngüsü ve iklim koşullarına tepkisinin bir ölçütüdür (Baxter ve Dilkes, 2012). Yapılan çalışmada temiz ve sulak alan habitatları yağışın daha fazla, sıcaklığın daha düşük olduğu Çaybaşı ilıçesinde, kirli alan habitatı ise yağışın daha az ve sıcaklığın daha yüksek olduğu Ünye illçesi'nde bulunmaktadır. Yaprak özellikleri üzerinde iklimin etkilerini belirlemek için yapılan çalışmalarda yaprak azotunun (kütle bazında) yağış ile spesifik bir eğilim göstermediği, yaprak fosforu ile ortalama yıllık yağış arasında güçlü bir ilişki olduğu belirlenmiştir (Ordóñez vd., 2009; Wright vd., 2005).

Tablo 4. Toprak Analiz Sonuçları

\begin{tabular}{|c|c|c|c|c|c|c|c|c|c|c|c|}
\hline L & $\begin{array}{l}\text { SiD } \\
(\%)\end{array}$ & SÇPH & $\begin{array}{l}\text { BYF } \\
\text { (kg/d } \\
\text { a) }\end{array}$ & $\begin{array}{c}\text { BYP } \\
(\mathrm{kg} / \mathrm{da})\end{array}$ & $\begin{array}{c}\text { BYK } \\
\text { (mg/kg } \\
)\end{array}$ & $\begin{array}{c}\text { BYM } \\
\text { (mg/kg) }\end{array}$ & $\begin{array}{c}\mathrm{T} \\
(\%)\end{array}$ & $\begin{array}{l}\text { OM } \\
(\%)\end{array}$ & $\begin{array}{c}N \\
(\%)\end{array}$ & $\begin{array}{c}K \\
(\%)\end{array}$ & B \\
\hline SA & 53.9 & $\begin{array}{l}7.44 \\
\text { Hafif } \\
\text { Alkali }\end{array}$ & $\begin{array}{l}7.37 \\
\text { Yeter } \\
\text { siz }\end{array}$ & $\begin{array}{l}44.46 \\
\text { Yeterli }\end{array}$ & $\begin{array}{c}4365 \\
\text { Yüksek }\end{array}$ & $\begin{array}{c}497.6 \\
\text { Yüksek }\end{array}$ & $\begin{array}{c}0.03 \\
\text { Az } \\
\text { Tuzlu }\end{array}$ & $\begin{array}{l}1.85 \\
\text { Orta }\end{array}$ & $\begin{array}{c}0.07 \\
\text { Yetersiz }\end{array}$ & $\begin{array}{c}2.35 \\
\text { Kireçli }\end{array}$ & Killi-Tınlı \\
\hline TA & 57.5 & $\begin{array}{l}7.29 \\
\text { Hafif } \\
\text { Alkali }\end{array}$ & $\begin{array}{l}7.01 \\
\text { Yeter } \\
\text { siz }\end{array}$ & $\begin{array}{l}52.85 \\
\text { Yeterli }\end{array}$ & $\begin{array}{c}4724 \\
\text { Yüksek }\end{array}$ & $\begin{array}{c}491.5 \\
\text { Yüksek }\end{array}$ & $\begin{array}{c}0.04 \\
\text { Az } \\
\text { Tuzlu }\end{array}$ & $\begin{array}{l}1.90 \\
\text { Orta }\end{array}$ & $\begin{array}{c}0.06 \\
\text { Yetersiz }\end{array}$ & $\begin{array}{c}3.13 \\
\text { Kireçli }\end{array}$ & Killi-Tınlı \\
\hline KA & 64.5 & $\begin{array}{l}8.25 \\
\text { Hafif } \\
\text { Alkali }\end{array}$ & $\begin{array}{c}14.75 \\
\text { Yeter } \\
\text { li }\end{array}$ & $\begin{array}{l}60.91 \\
\text { Yeterli }\end{array}$ & $\begin{array}{c}4587 \\
\text { Yüksek }\end{array}$ & $\begin{array}{c}512.2 \\
\text { Yüksek }\end{array}$ & $\begin{array}{c}0.02 \\
\text { Az } \\
\text { Tuzlu }\end{array}$ & $\begin{array}{c}4.22 \\
\text { İyi }\end{array}$ & $\begin{array}{c}0.13 \\
\text { Yeterli }\end{array}$ & $\begin{array}{c}8.25 \\
\text { Kireçli }\end{array}$ & Killi-Tınlı \\
\hline SD & $50-70$ & $7.5-8.5$ & $>3-4$ & $>30$ & $\begin{array}{c}1150- \\
3500\end{array}$ & $\begin{array}{c}160- \\
480\end{array}$ & $\begin{array}{c}0- \\
0.15\end{array}$ & $3-4$ & $\begin{array}{c}0.09- \\
0.17\end{array}$ & $5-15$ & \\
\hline
\end{tabular}

Tablo 4'de toprak analiz sonuçları verilmiştir. Bu sonuçlara bakıldığında her üç habitatın topraklarının su ile doygunluk değerleri sınır değerleri arasında olmakla beraber en yüksek değer kirli alan habitatında görülmüştür. Tüm habitatların toprakları hafif alkali, az tuzlu özellikte olup kireçli, killi- tınlı toprak tipindedir. Bitkiye yarayışı fosfor temiz alan ve sulak alanda yetersiz iken kirli alanda yeterli bulunmuştur. Bitkiye yarayışlı potasyum, kalsiyum ve magnezyum ise yeterli ve yüksek düzeydedir. Organik madde açısından kirli alanın temiz ve sulak alana göre daha iyi olduğu tespit edilmiştir. Kirli alan habitatında organik madde miktarının yüksek çıkmasının nedeni alanın fındık tarımı yapılan arazilere yakın olması olabilir. \%N konsantrasyonu da kirli bölgede yeterli iken temiz ve sulak alanda yetersizdir. Azot açısından yetersiz olan temiz ve sulak alan habitatlarındaki bitkilerin azot içerikleri yüksek, kirli alan topraklarındaki bitkilerde ise düşük çıkmıştır. Bu sonuç literatür ile paralelellik göstermektedir. Yapılan çeşitli bilimsel çalışmalarda düşük verimliliğe sahip toprakların besin elementlerini daha etkili bir şekilde kullandığını, yüksek verimliliğe sahip topraklarda ise daha az verimli kullanıldığı bildirilmiştir (Bilgin ve Güzel, 2017; Kılıç vd., 2010; Kutbay ve ark. 2003; Özbucak vd., 2011). 


\section{Sonuç ve Öneriler}

Sonuç olarak, farklı ekolojik özelliklere sahip üç farklı habitatta yayılış gösteren $P$. americana bitkisinin $\mathrm{N}$ ve $\mathrm{P}$ içeriklerinin lokalitelere ve bitkinin gelişme dönemlerine göre farklılık gösterdiği belirlenmiştir. Farklı ekolojik faktörlere ve bitkinin gelişme dönemine bağlı olarak bitki topraktan farklı miktarlarda besin elementi alabilmektedir. Bitkilerde besin elementi konsantrasyonunun besin kaynağı, toprak kök aktivitesi ile alınabilen miktar, floem ve ksilem yoluyla transfer edilebilme yeteneği gibi faktörlere göre değişlik gösterdiği ayrıca türlerin besin içerik değerlerinin fizyolojik ve fenolojik gelişme dönemlerine göre varyasyonlar gösterebileceği bilinmektedir. Bitki türlerinin bulundukları ortama uyum sağlamaları ve ekosistemlerin fonksiyonları açısından önemli biyolojik süreçler olan besin elementi dinamiklerinin farklı ekolojik ortamlardaki profillerinin ortaya konulması önemlidir. Yapılan bu çalışmanın bu bitki veya bu tür habitatlarda yapılacak diğer çalışmalara ışık tutacağı kanatindeyiz.

\section{Destek ve Teşekkür}

Bu araştırma yüksek lisans tezinin bir kısmından hazılanmış bir yayındır.

\section{Yazar Katkısı}

Tuğba Özbucak, deneysel ortamını hazırladı ve deneysel süreci takip etti. Arzu Sağlam, verilerin toplanması ve istatistiksel analizlileri gerçekleştirdi. Yazarlar makaleyi birlikte yazdı, okudu ve onayladı.

\section{Etik}

Bu makalenin yayınlanmasıyla ilgili herhangi bir etik sorun bulunmamaktadır.

\section{Çıkar Çatışması}

Yazarlar herhangi bir çıkar çatışması olmadığını beyan ederler.

\section{ORCID}

Tuğba Özbucak (iD https://orcid.org/0000-0002-4784-3537

Arzu Sağlam (iD https://orcid.org/0000-0002-3675-5144

\section{Kaynaklar}

Akçin, Yalçın, E. ve Akçin T A (2018). Spergularia marina (L.) Griseb. (Caryophyllaceae)'da tuzluluğun prolin ve klorofil pigmentleri üzerine etkisi. Sinop Üniversitesi Fen Bilimleri Dergisi, 2(1), 80-92.

Aktaş M. ve Ateş A. (1998). Bitkilerde beslenme bozuklukları nedenleri tanınmaları. Nurol Matbaacılık.

Allen S. E., Grimshaw H. M., Parkinson J. A., Quamby C. ve Roberts J. D. (1986). Chemical analysis. Chapman S. B. (Ed.), Method in Plant Ecology (pp. 411-466) içinde. Black well Scientific Publications Oxford.

Anonim, (2014b). Phytolacca americana. https://en.wikipedia.org/wiki/Phytolacca_americana adresinden 15.10.2021 tarihinde alınmıştır.

Baytop T. (1994). Türkçe bitki adları sözlügüü. Türk Dil Kurumu Yayınları.

Bhargava B. S. Ve Dhandar D. G. (1987). Leaf sampling technique for pomegranate (Punica granatum L.). Progressive Horticulture, 19, 96-199.

Bilgin A., Yalçın E., Kutbay H. G. Ve Kök T. (2004). Foliar N and P dynamics of Heracleum platytaenium (Apiaceae) in relation to edaphic characteristics along an elevation gradient in northern Turkey. Annales Botanici Fennici, 41, 85-93. 
Boerner R. E. J. ve Koslowsky S. D. (1989). Micrositevariations in soil chemistry and nitrogen mineralization in a beech maple forest. Soil Biology and Biochemistry, 21(6), 795-801. https://doi.org/10.1016/0038-0717(89)90173-9

Boşgelmez A., Boşgelmez i. ì., Savaş̧̧ı S. ve Paslı N. (2001). Ekoloji - Il (Toprak), Başkent Klişe Matbaacilık.

Chen, H., Reed, SC., Lü, X., Xiao, K., Wang, K. ve Li, D. (2021). Global resorption efficiencies of trace elements in leaves of terrestrial plants. Functional Ecology, 35, 1596-1602. https://doi.org/10.1111/1365-2435.13809

Davis P. H. (1988). Flora of Turkey and the East Aegean Islands (7. Basım). Edinburgh University Press.

Erbaş S \& Şenateş A. (2020). Ayçiçeği (Helianthus annuus L.)'nde azot ve kükürt gübrelemesinin verim ve kaliteye etkileri. Süleyman Demirel Üniversitesi Fen Bilimleri Enstitüsü Dergisi, 24(1), 217-225. https://doi.org/10.19113/sdufenbed.678524

Erdal I., Askın M. A., Küçükyümük Z., Yıldırım F. ve Yıldırım A. (2008). Rootstock has an important role on iron nutrition of apple trees. World Journal of Agricultural Sciences, 4, 173-177.

Fageria N. K., Baligar V. C. ve Jones C. A. (2011). Growth and mineral nutrition of field crops ( 3. Baskı). CRC Pres.

Foth H. D. (1984). Fundamentals of Soil Science (7. Baskı). John Wiley and Sons.

Gong H., Li Y., Yu T., Zhang S., Gao J., Zhang S. ve Sun D. (2020). Soil and climate effect on leaf nitrogen and phosphorus stoichiometry along elevational gradients. Global Ecology and Conservation, 23, e01138. https://doi.org/10.1016/i.gecco.2020.e01138

Gudade B. A., Thakur M. R., Ulemale R. B., Imade S. R. ve Bodhade M. S. (2009).Nutrient uptake, soil nutrient status and quality of new sunflower varieties as influenced by fertilizer levels. Journal of Soils and Crops, 19(2), 355-359.

Güzel Ş. (2017). Fırtına vadisi'nde bazi odunsu taksonların yüksekliğe bağlı makroelement değişimi ve rezorbsiyon [Doktora Tezi]. Recep Tayyip Erdoğan Üniversitesi.

Jayakumar K., Jaleel C. A. ve Vijayarengan P. (2007). Changes in growth, biochemical constituents, and antioxidant potentials in radish (Raphanus sativus L.) under cobalt stress. Turkish Journal of Biology, 31(3), 127-136.

Kacar B. (1984). Bitki besleme uygulama klavuzu. A.Ü. Zir. Fak. Yayınları.

Kacar B. ve Katkat V. (2010). Bitki besleme (5. Baskı). Nobel Yayın Dağıtım.

Kılıç D. D., Kutbay H. G. ve Özbucak T. B. Hüseyinoğlu, R. (2012). Nitrogen and phosphorus resorption in two sympatric deciduous species along an elevation gradient. Rev. Écol. (Terre Vie), 67, 409422. http://hdl.handle.net/2042/55932

Kulaç O. ve Bildirici N. (2020). Bursa-Gemlik ekolojik koşullarında farklı fosfor dozlarının azkan nohut (Cicer arietinum I.) çeşidinin verim ve verim öğeleri üzerine etkisi. Kahramanmaraş Sütçü Imam Üniversitesi Tarım ve Doğa Dergisi, 23(3), 697-704. https://doi.org/10.18016/ksutarimdoga.v23i53104.657530

Kutbay, H. G. ve Ok, T. (2003). Foliar N and P resorption and nutrient levels along an elevational gradient in Juniperus oxycedrus L. subsp. macrocarpa (Sibth. \& Sm.) Ball. Annals of Forest Science, 60(5), 449-454. https://doi.org/10.1051/forest:2003037

Mengoni A, Gonnelli C, Galardi F, Gabbrielli R. ve Bazzicalupo M. (2000). Genetic diversity and heavy metal tolerance in populations of Silene paradoxa L. (Caryophyllaceae): A random amplified polymorphic DNA analysis. Molecular Ecology, 9(9), 1319-1324. 
Milosevic T, Milosevic N, Glisic I \& Paunovic G. (2009). Leaf nutritional status and macronutrient dynamics in European hazelnut (Corylus avellana L.) under western Serbian conditions. Pakistan Journal of Botany, 41, 3169-3178.

Min, Y., Meizhen, T., ve Aoyama, I. (2007). Accumulation and uptake of manganese in a hyperaccumulator Phytolacca americana. Minerals Engineering, 20(2), 188-190. https://doi.org/10.1016/j.mineng.2006.06.003

Özbucak, T. B., Kutbay, H. G., Yalçın, S. ve Kılıç, D D. (2011). Foliar nitrogen (n), phosphorus(p) dynamics, and foliar resorption of Corylus avellana var. avellana. Ekoloji, 20(81), 1-7. https://doi.org/10.5053/ekoloji.2011.811

Özbucak T. B., Akçin Ö. E. ve Ertürk Ö. (2013). The change in ecological, anatomical and antimicrobiological properties of the medicinal plant Tilia rubra Dc. subsp. caaucasıca (Rupr.) V. Engler along an elevational gradient. Pakistan Journal of Botany, 45(5). 1735-1742.

Pastor-Pastor, A., González-Paleo, L., Vilela, A. ve Ravetta, D. (2015). Age-related changes in nitrogen resorption and use efficiency in the perennial new crop Physaria mendocina (Brassicaceae). Industrial Crops and Products, 65, 227-232. https://doi.org/10.1016/j.indcrop.2014.11.044

Penuelas, J., Poulter, B., Sardans, J., Ciais, P., Van Der Velde, M., Bopp, L., ... Janssens, I. A. (2013). Human-induced nitrogen-phosphorus imbalances alter natural and managed ecosystems across the globe. Nature communications, 4(1), 1-10. https://doi.org/10.1038/ncomms3934

Plaster E. J. (1992). Soil science and management (2. Baskı). Delmar Publishers Inc.

Roche P., Díaz-Burlinson N. \& Gachet S. (2004). Congruency analysis of species ranking based on leaf traits: Which traits are the more reliable?. Plant Ecology, 174(1). 37-48.

Xu, M., Zhu, Y., Zhang, S., Feng, Y. Zhang, W. ve Hana, X. (2021). Global scaling the leaf nitrogen and phosphorus resorption of woody species: Revisiting some commonly held views. Science of the Total Environment, 788, 147807. https://doi.org/10.1016/j.scitotenv.2021.147807

Yalçın E. (2018). Ekosistemlerde yaprağın ekolojik fonksiyonları. Black Sea Journal of Engineering and Science, 1(2), 68-82.

Yerli C., Çakmakçı, T., Sahin U. ve Tüfenkçi ş. (2020). Ağır metallerin toprak, bitki, su ve insan sağlığına etkileri. Türk Doğa ve Fen Dergisi, 9 (Özel Sayı), 103-114.

Zhao, L., Zhu, Y. H., Wang, M., Ma, L. G., Han, Y. G., Zhang, M. J., ... Zheng, X. K. (2021). Comparative transcriptome analysis of the hyperaccumulator plant Phytolacca americana in response to cadmium stress. 3 Biotech, 11(7), 1- 23. https://doi.org/10.1007/s13205-021-02865-x 